\title{
The Rise of Chinese Investments in Africa: For Whose Benefit?
}

\author{
Daniel N Mlambo, Victor H Mlambo, Mandla A Mubecua \\ University of Zululand, KwaDlangezwa, South Africa \\ mlambo1@ymail.com, halavico@yahoo.com,mubecua@gmail.com
}

\begin{abstract}
Ever since China's rise as a global superpower, there have been numerous debates about its role in Africa both from an Afrocentric and Eurocentric perspective. This is while some view its presence in Africa as that of a donor because of its growing investments, others are not entirely convinced and see China's rising footprints in Africa as another colonialist state in need of looting Africa its resources. By utilizing a qualitative methodology, this paper ponders Chinese investments in Africa with the view of assessing the drivers underpinning China-Africa relations and how this has been beneficial to both parties concerned. In this vein, the study shows that China-Africa engagements are not something new, their relations dates back for decades though became more prominent from the 1950s after the Bandung Conference. Since then, China has risen to be a prominent player with regards to investments in Africa. It has further established various institutes aimed at strengthening its grip as a noticeable state in Africa's development and political landscapes. The paper concludes by outlining that China has in some way benefited Africa through its investments over the past few decades and these relations have been beneficial to both parties. However, it argues that for more prosperous relations moving forward, African leaders should utilize institutes such as the Forum on ChinaAfrica Cooperation (FOCAC) to articulate clear policies for their engagement(s) with China and to protect their small and fragile economies from cheap Chinese imports.
\end{abstract}

Keywords: China, Africa, Investment, FDI, Infrastructure

\section{Introduction}

China's rapid rise as an Asian and Global superpower over the last few decades has attracted much attention from both scholars and policy analysts alike. It has gained so much prominence as a new global investor that is seen as a new challenger to the United States of America (USA), particularly as a result of its rapid investments (trade, aid, infrastructural development and information and communication technology) drive in Africa (Stahl, 2016). According to Large (2008) over the years and particularly from the 1950s, China has gained noticeable footsteps in Africa through its foreign policy, such that it has dramatically reduced the monopolistic of Western countries that have enjoyed massive footprints in Africa since the era of colonialism. However, he further contends that much of the attention paid to the nexus between China and Africa took place in a period where most African states were or about to gain their independence from their respective European colonial masters. Nevertheless, as often documented about the interests of European countries (pre and post-colonialism) in Africa in terms of them looting the continent of its resources, questions have emerged concerning the motive behind Beijing's investments in Africa. As Campbell (2008) asserts, this is because ever since the African continent arose from its colonial doldrums, it is no hidden fact that it has attracted both friends and looters. So what are the historical ties between China and Africa relations? While this will be unpacked in the subsequent chapter, the realignment of the Organization of African Unity (now African Union) also gave impetus to China making significant inroads within the continent. As the Organization of Africa Unity sort to develop the continent through economic and political integration, China took this opportunity to re-align its foreign policy and establish various agreements with the African community starting with re-enhancing infrastructural development in various African countries (Campbell, 2008).

Nevertheless, Schoeman (2008); Carrillo, Hood \& Kadetz (2017) contend that China's relations with Africa have over the years come with much scrutiny in the sense that like European countries, it is also after African resources as to meet the demands of its ever-increasing industrial and manufacturing sector(s). It is in this vein that there has been much scholarly debate about its true African intentions. So is China the new African colonizer? It is in this regard that the aim of this paper is to unearth the link between China and Africa since the inception of their relations, moreover, to delve on Beijing's push factor(s) for its relations with Africa and to further demonstrate who has been the beneficiary of this partnership China, Africa or both parties. Probing 
this ever-increasing Chinese investment in Africa is acute in drawing a nuanced, valid and vigorous standpoint on Beijing's role within Africa.

China-Africa Relations: From a Historical Perspective: According to Alden and Wu (2017) China's engagement with Africa is not a new phenomenon as their relations dates back to centuries ago to as far as (1368-1644) often known as the Ming Dynasty. During this time, Chinese explorers toured Eastern Africa with the command of Admiral Zheng He who was an explorer, mariner and diplomat. However, the founding of the People's Republic of China in 1949 propelled for more robust and progressive engagements between China and Africa. From the second quarter of the 1950s, China's relations with Africa started to take shape and was further spearheaded by the fact that some African states were gaining or about to gain their freedom from their respective European colonizers (Alden \& Alves, 2008). As Plummer (2003) affirms, these events presented Beijing with the platform to fully engage with African countries with regards to diverse investment opportunities. While progress was being attained here, a crucial moment in building these relations was accomplished during the Bandung Conference in 1955. This conference hosted Asian, African and Middle East countries and was viewed as a perfect platform to further enhance Asian-African cooperation (Stahl, 2016).

Here, former Chinese foreign minister Zhou Enlai ${ }^{1}$ had the privilege to fully engage with African heads of states and stressed that Africa and Asia had to work as a collective through economic, cultural and mutual benefits in order for them to improve their level of development. In this regard, post the Bandung conference, relations and diplomatic visits became more robust and numerous visits were taken by Chinese delegates to various African countries. For instance, Minister Enlai spent almost two months (seven weeks) in ten African countries $^{2}$ to intensify Africa-China relations through diplomatic driven missions from December 1963 to February 1964 (Shengnan, 2014). As a result of these diplomatic visits, in the same year (1964) China had already secured bilateral agreements with six African states. From 20 December 1982 to 17 January 1983, eleven African countries were also paid a visit by former Chinese premier Zhao Ziyang 3 to further strengthen South-South cooperation (Alden \& Alves, 2008).Basically, the Bandung conference presented China the prospect to make substantial inroads to African territories (Alden \& Alves, 2008).Over the years institutes such as the China-Africa joint research exchange plan, China - Africa people to people friendship action and China-Africa youth festival have jointly been established by Beijing and African countries as a tool of further stimulating their relations(Eisenman \& Heginbotham, 2018; Shinn \& Eisenman, 2012). According to Taylor (2011) in 2000, the Chinese government established the Forum on China-Africa Cooperation(FOCAC)as a mechanism to further stimulate and strengthen China-Africa partnerships (economically, politically and infrastructural). FOCAC aims to forge cooperation between African and China through South-South cooperation and to further promote China's long-term plans for African development. This forum usually takes place every three years with the first being held in Beijing in 2000, the last African country to host the FOCAC was South Africa in 2015 and Beijing will once again be the host for the forthcoming FOCAC in 2018 (Alden \& Wu, 2017).

\section{Chinese Investments in Africa: Who is the Beneficiary?}

According to Hogwe \& Banda (2017) China is currently viewed as one of the fastest emerging global power in the world and has often been compared to South Africa, India, Russia and Brazil. However, unlike these countries it is compared with, China has undertaken immense investments in Africa over the past three decades (Song \& Golley, 2011). These have been spearheaded by China's Official Development Assistance $(\mathrm{ODA})^{4}$ and its foreign policy to be a new donor to Africa's development as the continent is in dire need of Foreign Direct Investments (FDI) for its economic growth frameworks. Beijing has thus regarded Africa as a continent where it can extract its resources and the platform for Chinese firms to build their plant(s) and create employment opportunities (Thrall, 2015). However, China has often downplayed itself as a state in need of African resources for its economy rather portraying itself as another developing country intending to

\footnotetext{
${ }^{1}$ Was the first Premier of the People's Republic of China who served from 1949 to 1976.

2 These included the United Arab Republic (currently known as Egypt), Algeria, Morocco, Tunisia, Ghana, Mali, Guinea, Sudan, Ethiopia and Somalia.

${ }^{3}$ Served as the third Premier of the People's Republic of China from 1980 to 1987.

${ }^{4}$ Pertains to the transfer of finance and resources, these are made up of grants, technical assistance and loans. However, these exclude assistance pertaining to military loans or grants (Lola et al., 2017).
} 
be a recognizable driver to Africa's ${ }^{5}$ economic growth prospects. As often discussed in academic literature pertaining to China-Africa cooperation, a question that predominantly pops up has always been who benefits from these relations? As Besada (2013) points out, what is been done by Beijing in terms of African investments is what any global player would do as the case with various European countries and the USA. In this sense, Chinese investments in Africa include but not limited to the financing of large infrastructural projects, ever-increasing loans ${ }^{6}$ (see figure 1 and 2) debt cancellation, assist in nurturing human resources and granting African states the chance to access Chinese markets and as a result often filling the void in substantial components such as infrastructure and trade (Mlambo, Kushamba \& Simawu, 2016).

Figure 1: Showing top ten African loan recipients from China for the period 2000-2014.

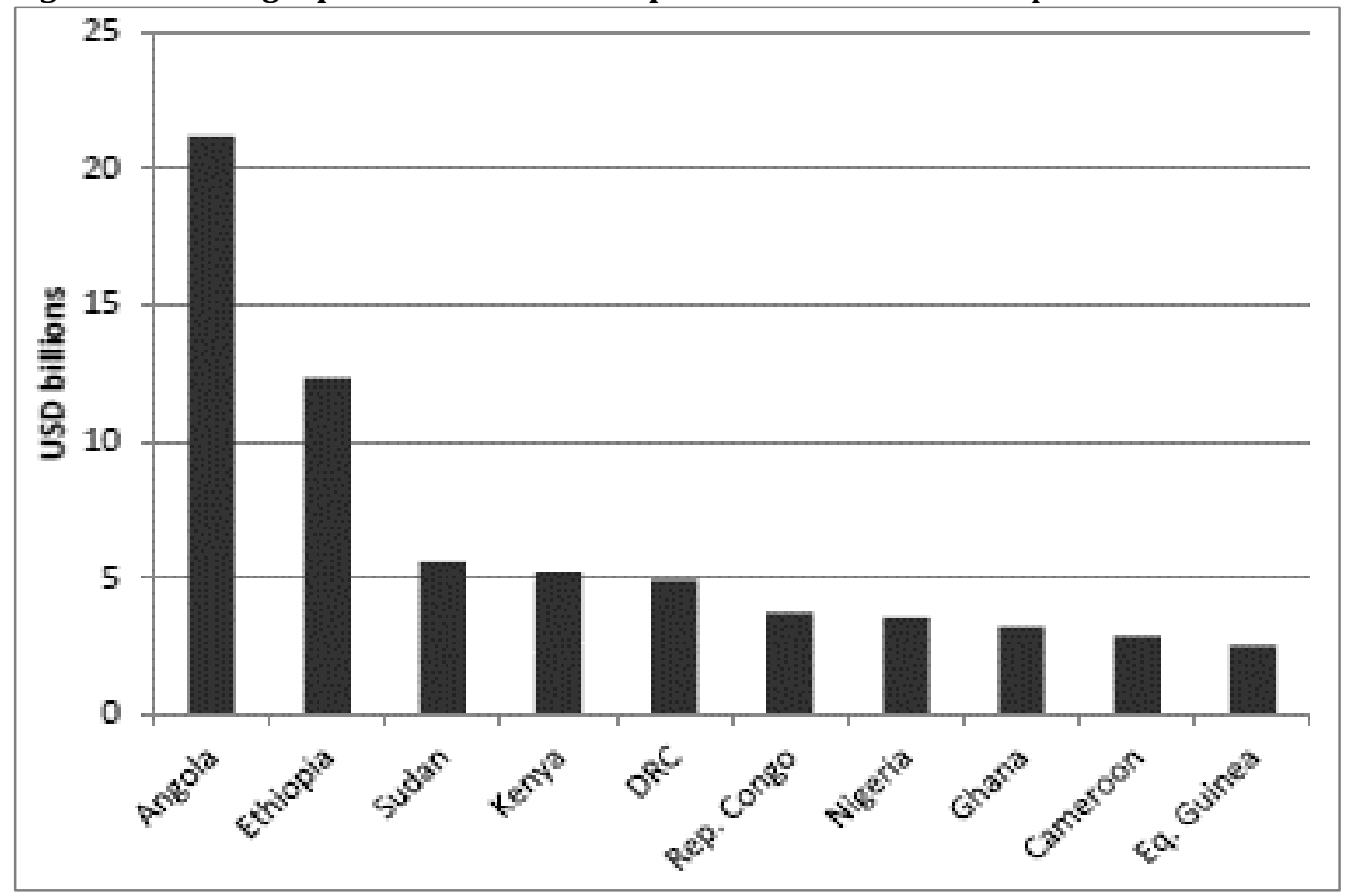

Source: Brautigam \& Hwang (2016).

Figure 2: Showing China's annual loans to African countriesfor period 2000-2015.

\footnotetext{
${ }^{5}$ While Beijing's trade in witnessed throughout the African continent, it is more significant in the Least Developed Countries (LDC's). From an African perspective, LDC's include Angola, Benin, Burkina Faso, Burundi, Central African Republic, Chad, Comoros, the Democratic Republic of Congo (DRC), Djibouti, Equatorial Guinea, Eritrea, Ethiopia, Gambia, Guinea, Guinea Bissau, Lesotho, Liberia, Madagascar, Malawi, Mali, Mauritania, Mozambique, Niger, Rwanda, Sao Tome and Principe, Senegal, Sierra Leone, Somalia, South Sudan, Sudan, Tanzania, Togo, Uganda and Zambia (Nowak, 2016).

${ }^{6}$ These loans are often in sectors that include transportation (rail, road and air), communication, dams, mining and energy (Brautigam \& Hwang, 2016).
} 


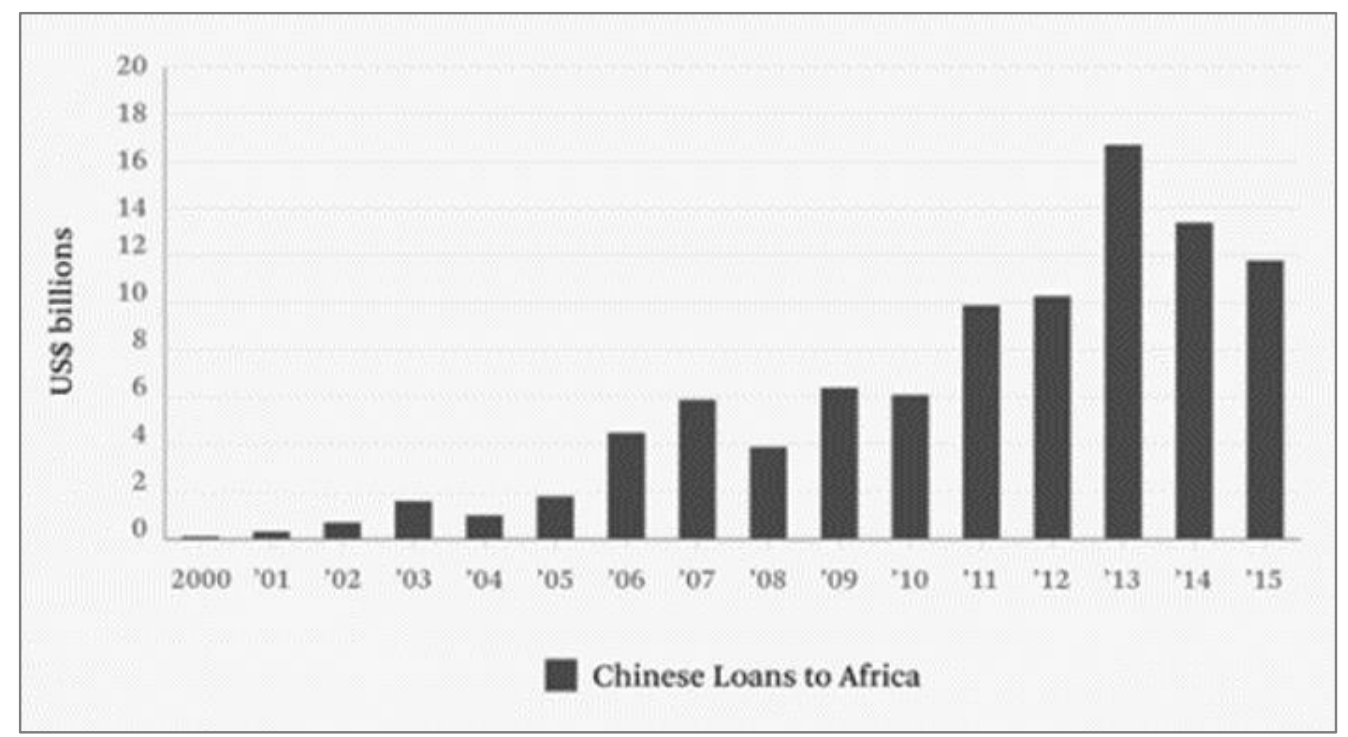

Source: China Africa Research Initiative (2017)

These infrastructural components include but not limited to the Addis Ababa-Djibouti railway, Kenya's Mombasa-Nairobi railway, the Kaleta Hydroelectric in Guinea and the Abuja-Kaduna rail line in Nigeria which have all been financed through Chinese aid. Hence, China was in 2015 (see table 1) the largest foreign donor in Africa with respect to trade.

Table 1: Showing top five foreign donors (trade) to Africa in 2015

\begin{tabular}{ll}
\hline Country & Amount(s) in US\$ (billion) \\
\hline China & 188 \\
India & 59 \\
France & 57 \\
USA & 53 \\
Germany & 46 \\
\hline
\end{tabular}

Source: Yuan Sun, Jayaram \& Kassiri (2017).

As a result of these investments from Beijing, scholars such as Tull (2006) contend that unlike western funding mechanisms which are more focused on reducing poverty levels in the continent, China is heavily focused on infrastructural and trade, a move that is often warmly received by African leaders. Apart from these investments, Beijing does not impose any political obligations in its dealing with African states and regularly invest in sectors where western donors are reluctant to (Ayodele \& Sotola, 2014).Over a decade ago in May 2005, former Zimbabwean president Robert Mugabe articulated that "We have turned east where the sun rises and given our backs to the west, where the sun sets" these words were as a result of the renowned appreciation of the FDI from China not only to Zimbabwe but African in general (Mugabe, 2005). So has the increased presence of China been a threat to Africa? For China and Africa, they see their relations being that of dual benefits where both are winners. By observing current China- Africa relations, it seems both parties are benefiting from their collaboration. China is able to attract needed resources while Africa is able to attract much needed FDI from Beijing. As a result of this, Africa seems to be gaining a lot from China and vice-versa coupled with the fact that Africa has openly continued to accept Chinese investments for its economic growth endeavours post the Bandung conference. This has gradually assisted Africa in critical infrastructural components.

Challenges Facing China's Engagement with Africa: As mentioned elsewhere in this paper, Beijing's dramatic rise in the global arena has been well documented, nevertheless, this dramatic rise has over the years come with its own challenges. As a result, things have not been as smooth as they seem as Beijing's investments in Africa have often come with severe criticism from the West and also in Africa. Drawing from 
the above, over the years China has failed to win over the trust of African civil society, labour unions and in some instances some African political parties. Therefore, it has vastly struggled to conduct itself in a manner to please these critical societal components. According to Zeleza (2014) Beijing's investments in Africa have often been challenged as a result of biased competitive and investments procedures, safety concerns for African workers, low wages, unable to duly comply with local labour laws and practices, incapable to attract and nature African workers and at times employing dictatorship rule in management positions ${ }^{7}$.Furthermore, small African businesses are severely affected by Chinese imports as a result of them being cheap and easily available. It has also been said that China does not adhere to enhance good governance in Africa due to the fact that it does not release accurate data on investments and aid undertaken in the continent (Jahanzeb \& Muneer, 2012; Sauls \& Heaton, 2016). This often leads to China being labelled an exploit nation with the objective of contributing to the continents de-industrialization (Brazinsky, 2017).

To some extent, this may seem relevant as Africa is a diverse continent comprising of Middle-Income Countries (MDCs) like South Africa, Nigeria, Ghana, Namibia and Botswana and LDC's. The latter countries may be the most affected by cheap Chinese imports as a result of their level of development and not possessing sufficient resources and in this regard may view China as a competition for their development and economic growth initiatives. According to Mlambo, Kushamba \& Simawu (2016) while facing criticism from Africa, the west has also been critical of Beijing's investments in Africa. To Western nations, Beijing is predominantly after Africa resources. China has often responded to this criticism by outlining that its development assistance to Africa aims to enhance the transfer of technology, create employment, enhance bilateral agreements and create robust multilateral relationships (Lola et al., 2017). Nevertheless, from a western viewpoint, China is a threat to Africa's development frameworks. These sentiments seem to be true as just recently (March 2018), the USA secretary of state Rex Tillerson toured five Africa countries. In Addis Ababa (Ethiopia) at the African Union (AU) headquarters (built by Chinese investments in 2011) Tillerson said "Chinese investments in Africa do not bring significant job creation locally "and further criticised how China structures its loans to African countries, this further shows what other nations think of Beijing's presence in Africa (Huanxin, 2018).As a result, these challenges may bring with it severe complications to current and future China-Africa relations and undoubtedly need to be addressed as so not to deter the present and future role of China's investments in Africa and its overall relations with the African continent.

\section{Methodology}

This paper embraced a mainly qualitative research approach by scrutinizing secondary sources to retrieve the required information on China-Africa relations. Researchers undertaking qualitative studies intend to gather a robust viewpoint pertaining to human behaviour and the rationale behind it (Creswell: 2003). As a result, the data drawn was exploited from books, chapters in books, journals, transcripts, news reports, newspaper articles together with reliable online sources. The dependency on secondary sources allowed for a robust and broader explanation of the topic under investigation. All retrieved data was subjected to the essential and extensive use of content analysis. Cole (1988) opines that content analysis is a technique used to analyse written text ranging from books, book chapters, newspaper articles, discussion notes, speeches, interviews, essays and documents. Basically, this analysis grants the researcher to validate theoretic text to better enrich the understanding of the gathered data. It pertains to focusing on every element of written text often supporting in shedding light on the topic under study.

China-Africa Relations: The Way Forward: According to Zhao (2015) China is currently regarded as one of Africa's largest partner in terms of trade and investments. However, while both seem to be reaping the rewards as a result of these relations, what does the future hold in terms of this ever blooming partnership. While China and Africa should continue with their relations as it has been prosperous particularly for Africa as it is in need of development and economic growth investments. Nevertheless, this foreign aid from China must intend on promoting African economic growth and be further aligned to the AU's agenda for African development. African leaders should also implement monitoring mechanisms in their engagement with China in the sense that Beijing must not loot Africa of resources critical for the continents own growth prospects both in the short and long term. China-Africa engagements should in future prioritize the protection of local

${ }^{7}$ These management positions are normally held by Chinese nationals. 
businesses from cheap Chinese imports that have severe effects on the growth of small and emerging businesses in specific African states. Therefore, African leaders should utilize their standpoint with China to further articulate clear mandates for their relations with Beijing notably their gains, challenges and what they hope to further achieve from their engagements with Beijing moving forward. Apart from this, there is a pivotal need for regional organizations such as the AU to play a crucial role as the middleman and watchdog in China-Africa cooperation presently and in future. With that said, these relations have seemed to be a good blessing in disguise for Africa thus far. However, this will solely depend on further mutual benefits for both parties moving forward.

\section{Conclusion and Recommendations}

China's rise as a global power has been well documented and has over the last few decades seem to be a blessing in disguise for most African nations, a move warmly welcomed by a continent that is the least developed from a global perspective. This paper has argued that China-Africa relations are not something new. However, it took further shape post the Bandung conference and further grew when most African countries gained or were about to gain their freedom from respective European colonizers. Since then, China has continued to make substantial inroads in Africa through its investments. This paper shows that both parties (China and Africa) are benefiting from this engagement, Africa through investments and China through gaining much-needed resources. Nevertheless, Beijing's African investments have also faced harsh criticism, especially from the West, often as a result of the manner in which it undertakes its business dealings in Africa. While Chinese's investments are greatly needed in Africa, the paper recommends that this should also promote African development in the short and long term. In essence, African heads of states and continental bodies should monitor their engagements with Beijing. This will also lead to the protection of minor African businesses from cheap Chinese imports that severely have a huge impact on their businesses. Hence, the FOCAC forum gatherings are good avenues to further articulate clear policies and objectives for China-Africa relations for both the present and future.

\section{References}

Alden, C. \& Alves, A. C. (2008). History and Identity in the Construction of China's Africa Policy. Review of African Political Economy, 35(115), 45-58.

Alden, C. \& Wu, Y. S. (2017). China Africa - Fact Sheet. http://www.saiia.org.za/special-publicationsseries/694-2015-china-africa-factsheet/fileAccessed 1 March 2018.

Ayodele, T. \& Sotola, 0. (2014). China in Africa: An Evaluation of Chinese Investments. http://www.ippanigeria.org/articles/China\%20-

Africa\%20relation_Workingpaper_final.pdfAccessed 10 March 2018.

Besada, H. (2013). Assessing China's Relations with Africa. Africa Development, 38(1-2), 81-105.

Brautigam, D. \& Hwang, J. (2016). Eastern Promises: New Data on Chinese Loans in Africa, 2000 to 2014. https://static1.squarespace.com/static/5652847de4b033f56d2bdc29/t/58ac91ede6f2e1f64a20d11 a/1487704559189/eastern+promises+v4.pdfAccessed 26 April 2018.

Brazinsky, G. A. (2017). Winning the Third World: Sino-American Rivalry during the Cold War. Chapel Hill. The University of North Carolina Press.

Campbell, H. (2008). China in Africa: Challenging US Global Hegemony. Third World Quarterly, 29(1), 89-108.

Carrillo, B., Hood, J. \& Kadetz, P. (2017). Handbook of China Welfare. Cheltenham, Edwards Elgar Publishing.

China Africa Research Initiative. (2017). Data: Chinese loans to Africa. http://www.sais-cari.org/datachinese-loans-and-aid-to-africa Accessed 25 April 2018.

Cole, F. L. (1988). Content Analysis Process and Application. Clinical Nurse Specialist, 2(1), 53-57.

Creswell, W. (2003). Research Design: Qualitative, Quantitative and Mixed Methods Approach. California, Sage Publications.

Eisenman, J. \& Heginbotham, E. (2018). China Steps Out: Beijing's Major Power Engagement with the Developing World. New York, Routledge.

Hogwe, F.\& Banda, H. (2017). The nature of China's role in development of Africa: The case of Zimbabwe. Problems and Perspectives in Management, 15(1-1), 237-247. 
Huanxin, Z. (2018). Tillerson talk on China role in Africa criticized.http://www.chinadaily.com.cn/a/201803/09/WS5aa2aa6ea3106e7dcc140bd1.htmlAcces sed 13 March 2018.

Jahanzeb, A. \& Muneer, S. (2012). Implication of behavioral finance in investment decision-making process. Information Management and Business Review, 4(10), 532

Large, D. (2008). Beyond 'Dragon in the Bush': The Study of China - Africa Relations. Africa Affairs, 107(426), $45-61$.

Lola, G. K., Rasiah, R., Teng, K. K., Muhammad, M. \& Agboola, Y. H. (2017). China's Aid and Oil for Infrastructure in Nigeria: Resource Driven or Development Motive? Contemporary Chinese Political Economy and Strategic Relations: An International Journal, 3(3), 1197-1235.

Mlambo, C. T., Kushamba, A. \& Simawu, M. B. (2016). China-Africa Relations: What Lies Beneath? The Chinese Economy, 49(2), 257-276.

Mugabe, R. G. (2005) in Bauer, J. (2013). The Flight of the Phoenix: Investing in Zimbabwe's Rise from the Ashes during the Global Debt Crisis. Berlin, Epuli GmbH.

Nowak, W. (2016). China-Africa and India-Africa Trade in the Years 2000-2014. Procedia Economics and Finance, 39, 140-146.

Plummer, B. G. (2003). Window on Freedom: Race, Civil Right and Foreign Affairs, 1945 - 1988. Chapel Hill, The University of North Carolina Press.

Sauls, P. R. \& Heaton, N. D. (2016). Consequences of Chinese Aid in Sub-Saharan Africa. Master's Thesis. Naval Postgraduate School, The United States of America.

Schoeman, M. (2008). China in Africa: Whose Challenge and Whose Opportunity. Africa Spectrum, 43(3), 403413.

Shengnan, Z. (2014). Zhou's visit to Africa had a lasting effect. http://www.chinadaily.com.cn/world/2014livisitafrica/2014-05/05/content_17483420.htm Accessed 29 May 2018.

Shinn, D. H. \& Eisenman, J. (2012). China and Africa: A Century of Engagement. Pennsylvania, University of Pennsylvania Press.

Song, L. \& Golley, J. (2011). Rising China: Global Challenges and Opportunities. Canberra, The Australian National University Press.

Stahl, A.K. (2016). China's Relations with Sub-Saharan Africa. http://www.iai.it/sites/default/files/iaiwp1622.pdfAccessed 27 February 2018.

Taylor, I. (2011). The Forum on China-Africa Cooperation. Abington, Routledge.

Thrall, L. (2015). China's Expanding Africa Relations: Implications for US National Security. Santa Monica, Rand Corporation.

Tull, D. M. (2006). China's Engagement in Africa: Scope, Significance and Consequences. The Journal of Modern African Studies, 44(3), 459-479.

Yuan Sun, I., Jayaram, K. \& Kassiri, O. (2017). Dance of the lions and dragons" How are Africa and China engaging, and how will the partnership evolve? https://www.mckinsey.com/global-themes/middleeast-and-africa/the-closest-look-yet-at-chinese-economic-engagement-in-africaAccessed 27 April 2018.

Zeleza, T. P. (2014). The Africa-China Relationship: Challenges and Opportunities. Canadian Journal of African Studies, 48(1), 145-169.

Zhao, S. (2015). China in Africa: Strategic Motives and Economic Interests. Routledge, Abington. 